\title{
SUCCESS FACTORS FOR POST-DISASTER PERMANENT HOUSING: EXAMPLE OF TURKISH EARTHQUAKES
}

\author{
Fatma KÜRÜM VAROLGÜNES \\ Bingöl University, Turkey \\ fkvarolgunes@bingol.edu.tr \\ https://orcid.org/0000-0002-3214-4274
}

\begin{abstract}
Investigating the social, economic and physical characteristics of settlements created after the disaster will raise awareness about reconstruction. In this study, firstly, a literature review was conducted in order to determine long-term satisfaction indicators for permanent housing use in resettlement areas. The data obtained are reduced and grouped with hierarchy and affinity diagrams. Qualitative data obtained from the literature were analyzed on nine settlements previously exposed to earthquakes in Turkey by model pairing and content analysis techniques. With this research, determining the indicators that affect long-term satisfaction (such as 50 years) will contribute to new research. As a result, it has been determined that the identity, lifestyle and employment opportunities of the victims are not taken into account in housing construction in Turkey in post-earthquake reconstruction. It was observed that most of the disaster housings built in the 50 years between 1970 and 2020 in Turkey do not carry the traces of the local texture. When the results of the study are examined, the importance of an approach that integrates environmental functions and socio-economic structure is seen in the creation of new residential areas. This holistic approach will ensure that community-based indicators are also included in the production of permanent housing. This study offers an important contribution in terms of determination of indicators influencing long-term satisfaction in resettlement programs by drawing attention to physical, social, cultural and economic factors in terms of permanent housings built after earthquakes in Turkey.
\end{abstract}

Keywords: Disaster management, Post-disaster permanent housing, Resettlements, Success factors, Turkish earthquake.

\section{AFET SONRASI KALICI KONUT UYGULAMALARINDA BAŞARI FAKTÖRLERININ BELİRLENMESİ: TÜRKIYYE DEPREMLERİ ÖRNEĞİ}

\section{ÖZ}

Afet sonrasında oluşturulan yerleşimlerin sosyal, ekonomik ve fiziksel özelliklerinin araştırılması, yeniden yapılanma konusunda farkındalık oluşturacaktır. Yapılan bu çalışmada, öncelikle, yerleşim alanlarında kalıcı afet konutları için uzun vadeli memnuniyet göstergelerini belirlemek için literatür taraması yapılmıştır. Elde edilen veriler hiyerarşi ve benzeşim diyagramı ile belli sayıya indirgenmiş ve gruplanmıştır. Literatürden derlenen veriler, Türkiye'de seçilmiş dokuz deprem bölgesi üzerinde model eşleştirme ve içerik analizi tekniği ile analiz edilmiştir. $\mathrm{Bu}$ araştırma ile uzun vadeli (50 y1l gibi) memnuniyete (veya eksikliğe) etki eden göstergeleri ortaya koymak, yeni çalışmalara 1şık tutacaktır. Yapılan araştırma sonucunda Türkiye'de, deprem sonrası yeniden yapılanmada, afetzedelerin kırsal kimliğinin, yaşam tarzının ve iş olanaklarının konut inşasında yeterince dikkate alınmadığı tespit edilmiştir. Türkiye'de 1970 yılından 2020 yılına kadar geçen 50 yıllık süre zarfında yapılan afet 
konutlarının çoğunun yerel dokudan izler taşımadığı görülmektedir. Çalışmanın sonuçları incelendiğinde, yeni yerleşim alanları oluşturulmasında çevresel işlevler ile sosyo-ekonomik yapıyı bütünleştiren bir yaklaşımın önemi görülmektedir. Bu bütüncül yaklaşım, dayanıklı kalıcı konut üretimine, toplum temelli ölçütlerin de dâhil edilmesini sağlayacaktır. Bu çalışma, Türkiye'de deprem sonrası inşa edilmiş kalıcı konutlar özelinde; fiziksel, sosyal, kültürel ve ekonomik faktörlere dikkat çekerek, yeniden yerleşim programlarında uzun vadeli memnuniyeti etkileyen göstergelerin belirlenmesi için önemli katkı sunmaktadır.

Anahtar kelimeler: Afet yönetimi, Afet sonrası kalıcı konutlar, Yeniden yerleşim, Başarı faktörleri, Türkiye depremleri.

\section{INTRODUCTION}

Disasters occur as a result of the interaction of a risk or danger and societies that are not protected and prepared for them. The rate of being affected by these disasters of residential areas that develop due to the increasing population around the world and our country also rises. There is broad consensus on the fact that the number and cost of natural disasters are increasing worldwide (Freeman, 2004: 429). Especially earthquakes that occur unexpectedly are major disasters that cause deaths, injuries and material and moral damages. Earthquakes significantly affect the local housing market and liveability of the region where they occur (Boelhouwer \& van der Heijden, 2018: 5). For this reason, the success in resettlement and in rebuilding processes is critical in terms of the rapid recovery of earthquake victims and the lower levels of damage to the national economies of the countries (Peacock et al., 2018: 571). However, the necessity of providing housing in shortest period of time leads to the creation of residential areas where cultural and local conditions are not taken into account and the needs and satisfaction of the occupants are ignored in regions have no preparation for an earthquake (Johnson, 2007: 40). The most important building type that reflects the identity of the physical environment and social structure in which we live is housing. Therefore, the residential areas formed by buildings affect the daily life, social relations, and psychological status of individuals in addition to the functioning of the socio-economic order. These values are lost together with the demolition of the physical environment after a disaster. In order to correct this negative condition, the relationships between the individual and the environment where he/she lives should be accurately determined. The housing projects should not be considered only as a solution to the sheltering problem, whereas, it should be handled as an action of creating a physical environment that meets all social needs (Limoncu \& Bayülgen, 2005: 18; Sey \& Tapan, 1987: 52).

Designs that emerge without spatial surveys and user participation will lead to disaster victims' dissatisfaction and make them leave their settlements (Dikmen \& Elias-Ozkan, 2016: 167). In every partially or completely new settlement to be constructed, connections, which will provide social and economic benefits, with the old settlement, should be established as planning criteria (Aysan \& Oliver, 1987). The need for shelter after an earthquake and the sheltering processes created accordingly are carried out in four stages: emergency shelter, temporary shelter, temporary housing and permanent housing (Félix et al, 2015: 689; Quarantelli, 1995: 48). Emergency and temporary shelter are realized in the emergency aid phase in which the short-term shelter needs of earthquake victims are met. The main feature that distinguishes emergency aid shelters from other shelters is that they can be used for a short time after the disaster (Davidson et al, 2007: 110). Temporary housing is defined as the prefabricated housing where survivors after an earthquake can live temporarily (approximately from 6 months to 3 years) and perform their daily activities (Peacock et al, 2018: 575). The fourth stage is permanent housing built in the same area or in a new residential area after the earthquake. The healthy and fast implementation of this process depends on the proper management of the factors such as economic conditions, disaster management system, local land use and housing build. In this process, architects and urban planners play a very important role. The reason for this is that while creating new living environments, it should be ensured that people are able to maintain their normal social lives in health and feel a sense of belonging and trust in this environment (Lagorio, 1990). However, problems occur in this context in serial production of permanent housing, since the time and place cannot be foreseen and production volume and duration are limited in this kind of mass production. Changes are

Submit Date: 11.10.2020, Acceptance Date: 15.11.2020, DOI NO: 10.7456/11101100/007

Research Article - This article was checked by iThenticate

Copyright $\odot$ The Turkish Online Journal of Design, Art and Communication 
made in many residences as a result of dissatisfaction. These changes are made in the form of replanning, changing room functions, adding or removing new spaces with the aim of adopting the house to the user's life style (Davidson et al, 2007: 112). In this study, a literature review related to permanent housing constructed after earthquakes occurred since 1970 in different parts of Turkey was conducted. Thus, the successes and failures of the earthquake housing produced in Turkey were determined and solution proposals were made. The primary objective of this study is to create awareness about the creation of permanent housing reserve areas within the works done for preparing for the earthquake in Turkey. These houses should be designed in line with sustainable housing principles, taking into account the natural environmental factors such as the region's cultural structure, climate, topography, local elements.

When the world literature is reviewed, some criteria have been determined to discuss the permanent housing success after the disaster. In the study, these criteria were compiled and evaluated over Turkey samples. Housing reconstruction after the disaster in Turkey was first recorded in the 1509 Istanbul Earthquake, but the studies on the earthquake entered the architectural literature in 1977 (Baradan, 2008). In this study, studies available in the literature on rural settlements, especially following Gediz (1970), Bingöl (1971), Lice (1975), Erzurum-Kars (1983), Erzincan (1992), Dinar (1995), East Marmara (1999), Bingöl (2003) and Van (2011) earthquakes, were reviewed. The findings of the study were obtained from on-site investigations, interviews with disaster victims and surveys. While Lice, Erzincan, Erzurum-Kars, Bingöl and Van permanent earthquake houses could be examined on-site by the author, Gediz, Dinar and East Marmara permanent earthquake houses were interpreted over the literature reviews. In the study, the reasons for the abandonment of post-earthquake permanent housing settlements (especially in rural areas) or their being modified by the users were questioned.

1. The effects of reconstruction process implemented after the earthquakes occurred in Turkey on settlements' social, economic and physical dimensions,

2. The effects of the processes of in situ reconstruction and relocation on earthquake victims in the damaged areas,

3. The proposals for the reconstruction of the regions where earthquakes may occur in the future given the fact that Turkey is vulnerable to earthquakes,

\section{THE CONCEPTUAL FRAMEWORK}

Researchers argue that the physical, economic, social, cultural, and psychological characteristics of the settlements are not addressed in a holistic manner during the design process of permanent housings (PHs) after the earthquake. It is stated that especially in developing countries, due to the wrong and unqualified approaches in the understanding of disaster management and the inadequacies in the economy, the damages are increased, and these make post-disaster improvements efforts difficult (Ishiwatari, 2014: 79). Investigations done on the available resources related to the adaptation processes of settlements damaged by natural disasters (especially earthquakes) in different countries of the world reveal that the reconstruction methods determined by the planners vary according to the parameters such as the location of the rural area and the extent of the damage (e.g. recovery, integration, resettlement, reconstruction) (Einali et al, 2020: 201). Furthermore, some studies emphasized that longer use of the housings in post-disaster settlements will be ensured with human-centered housing production (Kürüm Varolgüneş, 2020).

Gomaa and Sakr (2015) summarized the success factors to create successful settlements by revealing the basic elements as increasing social cohesion, preserving the cultural character and sense of place, creating a safe environment. Similarly, Dias et al. (2016) emphasized in their study that while creating new settlements and building projects, it is not enough to consider only infrastructure and environmental issues and that the prepared projects should contribute to the enhancement of the socio-economic development level of the society. Manatunge and Abeysinghe (2017) stated in their study that despite the significant amount of funds provided after the Tsunami occurred in Sri Lanka, the structure of the 
society was not taken into account in the reconstructed settlements thus, the opportunity to plan sustainable settlements was missed. In general, they stated that, the satisfaction of the disaster victims in the settlements included in the study could not be achieved in the long term, due to many physical, environmental, and socio-economic factor. Kennedy et al. (2008) emphasized that local community satisfaction in the reconstruction process was crucial in terms of ensuring housing resettlement programs' long-term sustainability and utilization. Similarly, according to Ophiyandri et al. (2016), community-based resettlement programs play an important role in creating resilient communities in disaster areas. The individual's sense of belonging to the place, where he/she lives, and sense of identity will increase the housing value and therefore the occupant's satisfaction from the housing. While designing permanent housing, the housing structure (cultural, social and natural characteristics) specific to the region must be taken into consideration (Hamilton, 2012). Similarly, according to Davidson et al. (2007), community satisfaction must be prioritized in post-disaster resettlement to ensure the long-term participation of communities to rebuilding their socio-economic lives. These papers reveal that the satisfaction of communities in resettlement areas is extremely important in terms of ensuring the sustainability and success of post-disaster housing development projects. Unfortunately, in housings produced after the earthquake in Turkey, rather than addressing the social and cultural needs of disaster victims, only physical characteristics are taken into account.

In Turkey, during the building of the post-earthquake permanent housing, rather than the social and cultural needs of the victims are only taken into account physical characteristics (Coburn et al, 1984: 52; Aysan, 1985: 25; Aysan \& Oliver, 1987). Enginöz (2004) emphasized that the demands of the occupants and physical characteristics of the regions were not considered in the permanent housing practices in Turkey after he analyzed the permanent housings built in Dinar following the 1995 earthquake. Limoncu and Bayulgen (2005) analyzed the three-phase shelter approach (emergency phase, rehabilitation phase, reconstruction phase), which they determined in their study, under 6 different earthquake samples selected in Turkey and detected that there were not any certain strategies in these three steps and put forward the need of a sustainable sheltering system. In their study, İnal and Ünlü (2009) argued that most of the PHs built in Turkish rural areas were designed independently from the occupant demands and physical conditions of the region, and therefore, the PHs were not being used. In their study, they emphasized that the residential areas formed by the practices in which individuals are organized for producing their own solutions are more successful. Kilc1 et al. (2015) developed a method for the selection of temporary housing areas by identifying the mistakes made in the determination of sheltering areas following the 2011 Van Earthquake. Similarly, in their article, Platt and Drinkwater (2016) address post-disaster response and recovery in disaster management in Turkey. They discuss the findings from a real-time event, the Van Earthquake, and a scenario planning exercise in Izmir. The findings from both Van and the exercise point out a focus on immediate decisions at the expense of long-term planning that would be sensible to address. In conclusion, this paper recommends an approach to post-earthquake management in Turkey that balances the immediate needs of speed in rebuilding the infrastructure and economy with longer-term planning goals of maintaining and enhancing the quality of life and improving not only the safety but also the resilience of the urban fabric (Platt \& Drinkwater, 2016: 229). The sustainability of life in the residential areas following a disaster in terms of physical, social, cultural and economic aspects will also enable the long-term use of the permanent housings (Kürüm Varolgüneş, 2020).

\section{METHODOLOGY}

The most important stage of the post-earthquake activities is to solve the permanent housing problem. Post-earthquake residential areas are mostly formed based on the opinion of creating a safe place where the disaster victims can shelter immediately. Production of housing in fast and economical way, in a certain quality and in a sufficient number does not always give successful results. One of the two most important problems encountered during the production of permanent housing is the design of housing not compatible with the lifestyles of the earthquake victims, and the other one is the relocation of residential areas. In both cases, since the lives of the individuals and their conformity to natural 
conditions are not taken into account, the houses are either changed or abandoned in a short time. In their study, Coburn et al. (1984) argued that there was an unequal development performance in new residential areas in Turkey. They also stated in their studies that the success of the resettlements depends on the ability to be self-sufficient and the creation of suitable environments for the habits of the old settlements.

In this context, the main aim of this study is to determine the indicators affecting the long-term satisfaction of the victims in post-disaster permanent housing (Coburn et al, 1984: 52). Therefore, current literature has been reviewed to identify the main problems encountered in post-disaster permanent housing construction in disaster management. In order to reduce the data obtained by the literature review to a certain number of criteria, affinity (Shafer et al, 2005) and hierarchy (tree) diagrams were used. The main indicators were determined by making groupings with these diagrams. Data organized in groups at the first stage with affinity diagrams were rearranged analytically with tree diagrams (Guri-Rozenblit, 1989: 239) in a hierarchical scheme. Thus, the indicators included in a certain systematic were provided to be evaluated comprehensively (Table 1). As a part of the study approach, regions where earthquakes occurred in Turkey after 1970 and caused massive damage in the society, were selected (Table 2) (AFAD, 2018). The qualitative data obtained from the literature were analysed on nine selected seismic zones in Turkey through model matching and content analysis techniques. Detection of the indicators, that affect long-term (such as 50 years) satisfaction (or deficiency), with this study, will shed light on new studies.

Table 1. Findings of different authors led to identify success factors

\begin{tabular}{|l|l|}
\hline Success factor & Findings of different authors led to identify success factors \\
\hline Site-selection process & $\begin{array}{l}\text { New settlements were abandoned by occupants due to their distance from } \\
\text { fields and water resources (Aysan \& Oliver, 1987; Coburn \& Spence, } \\
\text { 2002). } \\
\text { New residential areas were abandoned due to neglect of climatic conditions } \\
\text { and leaving out of the use of valuable agricultural land (UNDRO, 1982). } \\
\text { The fact that the residential areas were positioned in locations far from the } \\
\text { agricultural areas formed an important problem in terms of the economic } \\
\text { status of the earthquake victims (Aysan, 1985: 25). }\end{array}$ \\
\hline $\begin{array}{l}\text { Meeting the user } \\
\text { requirement }\end{array}$ & $\begin{array}{l}\text { In permanent housing production, the livelihoods and employment } \\
\text { conditions of the users were not taken into account (Oliver-Smith, 1991: } \\
\text { 15). } \\
\text { Traditional lifestyles of permanent housing users were not taken into } \\
\text { account (Enginöz, 2004:18). } \\
\text { Crowded family structure in rural life was not taken into account (İnal \& } \\
\text { Ünlü, 2009:104). }\end{array}$ \\
\hline Housing design & $\begin{array}{l}\text { Housing design is a key factor for long-term satisfaction (Steinberg, 2007: } \\
\text { 152). } \\
\text { The fact that the housing designs are made with victims and the houses } \\
\text { belong to the victims positively affects the satisfaction. (Perera et al, 2012: } \\
10) . \\
\text { In order to meet the needs of the users that may change over time, } \\
\text { flexibility should be provided in the design. Creation of insufficient } \\
\text { physical space should be prevented (Limoncu \& Bayülgen, 2005: 18). }\end{array}$ \\
\hline $\begin{array}{l}\text { Considering regional knowledge and skills in building technique, design, } \\
\text { and material quality, and enabling disaster victims to create their own } \\
\text { housing solutions affect the success of permanent housing. (İnal \& Ünlü, } \\
\text { 2009:103). }\end{array}$ \\
\hline haterials used for
\end{tabular}




\begin{tabular}{|c|c|}
\hline & $\begin{array}{l}\text { Limited knowledge about local conditions, not investigating the way in } \\
\text { which the society live and work and the lack of experience affect permanent } \\
\text { housing success (Hayles, 2010: 110). } \\
\text { Including victims in the permanent housing building process will affect } \\
\text { satisfaction (Takesada et al, 2008: 247). } \\
\text { Owner-driven approach shows a higher satisfaction score compared to } \\
\text { donor-driven approach (Karunasena \& Rameezdeen, 2010: 181). } \\
\text { Residential satisfaction is determined by the sub-conditions of pavements, } \\
\text { width of streets, safety perception, residence aesthetics and aesthetics of the } \\
\text { housing (Tas et al, 2007: } 3420 \text { ). } \\
\text { Re-localisation in the context of regrowth (Dias et al, 2016: 588). } \\
\text { Encourages local production (Dias et al., 2016:584). }\end{array}$ \\
\hline $\begin{array}{l}\text { Empowerment of the } \\
\text { community }\end{array}$ & $\begin{array}{l}\text { Instead of presenting the housing ready to people, creating settlements } \\
\text { where users are organized to produce their own solutions (with user } \\
\text { participation) will provide long-term satisfaction (Coburn \& Spence, 2002). } \\
\text { It is necessary to increase the participation of non-governmental } \\
\text { organisations (NGOs) and disaster victims to the construction process } \\
\text { (Arslan, 2007: 402). } \\
\text { Allowing the community to design their houses by themselves is a factor } \\
\text { for long-term satisfaction (Perera et al, 2012:10). } \\
\text { Mobilisation and recruitment of local builders, skilled artisans, volunteers } \\
\text { and/or beneficiaries (Bilau et al, 2017: 29). } \\
\text { Provision of financial assistance such as micro loans is also a success factor } \\
\text { to ensure the long-term satisfaction. This allows the community to rebuild } \\
\text { their livelihood or even to adapt to a new livelihood (Perera et al., 2012: } \\
\text { 10). } \\
\text { Livelihood reconstruction as another success factor for the long-term } \\
\text { satisfaction of the resettled communities' (Steinberg, 2007: 150). } \\
\text { Rehabilitation of livelihoods (Dias et al., 2016: 584). }\end{array}$ \\
\hline $\begin{array}{l}\text { Easy and fast } \\
\text { production }\end{array}$ & $\begin{array}{l}\text { Fast and economical production should be evaluated together with } \\
\text { meeting the long-term requirements (Enginöz \& Ünlü, 2010). } \\
\text { Higher production rates, reduced construction time, better quality and } \\
\text { acceptable housing (Fallahi, 2007: 26). }\end{array}$ \\
\hline Building quality & $\begin{array}{l}\text { Provide health and safety needs (İnal \& Ünlü, 2009: 103). } \\
\text { In building construction, quality standards such as safety and durability } \\
\text { should be provided with priority (Fallahi, 2007: 26) }\end{array}$ \\
\hline $\begin{array}{l}\text { Provision of social } \\
\text { infrastructure }\end{array}$ & $\begin{array}{l}\text { Considering the social, cultural and economic life (Limoncu \& Bayülgen, } \\
\text { 2005: 18). } \\
\text { Post-disaster reconstruction should "build back better" in terms of safety, } \\
\text { security and livelihoods (Kennedy et al, 2008: 24). } \\
\text { The aim of re-localisation is to facilitate the development of self-reliant } \\
\text { global regions based on the principles of degrowth to foster economic and } \\
\text { ecological sustainability and social equity across the globe (Davoudi \& } \\
\text { Madanipour, 2015). }\end{array}$ \\
\hline
\end{tabular}


Table 2. Earthquakes that occurred between 1970-2018 in Turkey in which loss of life was high (Edited by the author).

\begin{tabular}{|c|r|c|c|c|}
\hline Date & Magnitude & Locat & Loss of & Severely damaged \\
\hline 28.03 .197 & 7.2 & Gediz (Kütahya) & 1.086 & 23.987 \\
\hline 22.05 .197 & 6.8 & Bingöl & 878 & 9.111 \\
\hline 06.09 .197 & 6.6 & Lice (Diyarbakır) & 2.385 & $8.450+7.710$ \\
\hline 30.10 .198 & 6.9 & Erzurum-Kars & 1.155 & 3.241 \\
\hline 13.03 .199 & 6.8 & Erzincan & 653 & 8.057 \\
\hline 01.10199 & 6.1 & Dinar (Afyon) & 90 & 14.156 \\
\hline 17.08 .199 & 7.5 & Doğu Marmara & 18.373 & 352.000 \\
\hline 01.05 .200 & 6.4 & Bingöl & 184 & 7.800 \\
\hline 23.10 .201 & 6.7 & Van & 604 & 11.232 \\
\hline
\end{tabular}

Reference: Disaster and Emergency Management Authority (AFAD, 2018)

\section{FINDINGS AND DISCUSSION}

Plans for permanent housings were developed and implemented in Turkey after 1970. However, the reactions of the occupants measured after the application and the researches conducted showed that the permanent housings were not technically successful and they remained insufficient in terms of satisfying the occupant. Since the economic and social structure of the society who will live there is almost never taken into consideration while preparing the settlement plans of the residences, the relation between the non-residential needs (employment opportunities, social needs) and the residential areas are neglected. Moreover, due to the lack of real policies related to post-earthquake sheltering and only application of temporary post-disaster practices, solving the sheltering problem take much longer time than planned. In this section, eight indicators affecting the satisfaction of disaster victims in permanent disaster housing and in the resettlement areas were reviewed by considering disaster housing in nine regions identified in Turkey. As a result of a detailed examination of the indicators, they were found to be related with each other. The subsections below discuss each indicator determined in the analysis.

\section{Site-selection process}

Site selection, which is one of the most important stages of reconstruction after a natural disaster, is handled by planners in two ways. If the areas are not geologically secure, the settlements are made in a new area. Settlement patterns created during the site selection stage should be determined based on the relationships between topographic conditions, climate effects, and user needs. Since the settlements planned in a solid geometric form are contrary to the natural pattern created by the society, the longing for old houses increases. The user satisfaction has not been achieved in settlements built after major earthquakes occurred in Turkey.

Generally, decision-makers consider that settlement area change is an appropriate solution as a technical criterion for ground safety and they completely ignore the relations of land, culture, and life. For example, the new residential areas that were constructed following the $1970 \mathrm{Gediz}$ and 1971 Bingöl earthquakes were abandoned by the occupants due to their remoteness to fields and water resources (Aysan \& Oliver, 1987; Coburn \& Spence, 2002: 52). While discussing the successes and failures of the resettlement constructed after the Bingöl earthquake occurred in 1971, Coburn et al. suggested that three factors were very important for success. These factors are the physical environment of the new settlement, its relationship with the old village and the society's ability to develop itself (Coburn et al, 1984: 51). The temporary and permanent housings built after the 1975 Lice earthquake were also not adopted by the local people and were not used for a long time. In the new residential areas, climatic conditions were not taken into consideration, valuable agricultural areas were remained out of use, and water could not be provided (UNDRO, 1982). Various changes were made in the temporary and permanent housings, which were built after the earthquake occurred in the Erzurum-Kars region in 1983, by the earthquake victims in a short period according to their needs. The number of family members and 
the cultural and economic conditions of the earthquake victims had an important effect on these changes. The fact that the residential areas were far from the agricultural areas formed an important problem in terms of the economic conditions of the earthquake victims (Aysan, 1985: 28). Similarly, having investigated the permanent housings that were built in Dinar following the 1995 earthquake Enginöz emphasized that the demands of the occupants and physical characteristics of the regions were not considered in the permanent housing practices in Turkey (Enginöz, 2004: 22). Inal and Ünlü (2009) stated in their study that in some settlements built after the 1999 earthquake, houses were left empty for many years without being used. In their study, they emphasized that the residential areas formed with the practices in which individuals were organized for producing their own solutions were more successful. Kürüm Varolgüneş (2020) stated that the residential areas constructed after the 2003 Bingöl earthquake either were changed or completely abandoned. K1lc1 et al.(2015) developed a method for the selection of temporary housing areas by identifying the mistakes made in the determination of sheltering areas following the 2011 Van Earthquake. User satisfaction related to residential areas created after the earthquake in Turkey was presented in Table 3.

Table 3. User satisfaction related to site selection after earthquakes occurred in Turkey

\begin{tabular}{|c|c|c|c|}
\hline \multicolumn{4}{|c|}{ Choosing the suitable settlements } \\
\hline & Old settlement & New settlement & User Satisfaction \\
\hline 1970 Gediz & $\begin{array}{l}\text { Built in Akçalan } \\
\text { village's old } \\
\text { settlement. }\end{array}$ & $\begin{array}{l}5 \mathrm{~km} \text { far from the } \\
\text { residential area } \\
\text { (Özkan, 1972: 26). }\end{array}$ & $\begin{array}{l}\text { New settlements were abandoned by } \\
\text { occupants due to their distance from } \\
\text { fields and water resources (Aysan \& } \\
\text { Oliver, 1987). }\end{array}$ \\
\hline 1971 Bingöl & & $\begin{array}{l}\text { It was moved to an } \\
\text { area that was } 4 \mathrm{~km} \\
\text { far from the old } \\
\text { settlement area. }\end{array}$ & $\begin{array}{l}\text { It was abandoned due to the distance } \\
\text { to the old settlements (Coburn et al, } \\
\text { 1984: 49). }\end{array}$ \\
\hline 1975 Lice & & $\begin{array}{l}\text { It was moved } 2 \mathrm{~km} \\
\text { south of the old } \\
\text { settlement. }\end{array}$ & $\begin{array}{l}\text { The temporary and permanent } \\
\text { housings built were not adopted by } \\
\text { the local people and were not used for } \\
\text { a long time. In the new residential } \\
\text { areas, climatic conditions were not } \\
\text { taken into consideration, valuable } \\
\text { agricultural areas were remained out } \\
\text { of use, and water could not be } \\
\text { provided (UNDRO, 1982). }\end{array}$ \\
\hline $\begin{array}{l}1983 \\
\text { Erzurum- Kars }\end{array}$ & & $\begin{array}{l}\text { The location of } \\
\text { determined areas did } \\
\text { not conform to the } \\
\text { traditional form } \\
\text { sheltered settlement } \\
\text { (Aysan, 1985: 23). }\end{array}$ & $\begin{array}{l}\text { The fact that the residential areas } \\
\text { were far from the agricultural areas } \\
\text { formed an important problem in terms } \\
\text { of the economic conditions of the } \\
\text { earthquake victims (Aysan, 1985: 23). }\end{array}$ \\
\hline 1992 Erzincan & $\begin{array}{l}\text { "Aid to those who } \\
\text { build their home" } \\
\text { practice was } \\
\text { implemented for } \\
\text { areas where less } \\
\text { than } 15 \text { houses } \\
\text { were planned. }\end{array}$ & $\begin{array}{l}\text { Areas belonging to } \\
\text { the treasury or legal } \\
\text { entities were } \\
\text { identified near the } \\
\text { old settlements and } \\
\text { opened for } \\
\text { construction. }\end{array}$ & $\begin{array}{l}\text { It is stated that this was handled } \\
\text { differently than those built in previous } \\
\text { earthquakes and more satisfaction } \\
\text { was achieved. }\end{array}$ \\
\hline $\begin{array}{l}1995 \text { Dinar- } \\
\text { Afyon }\end{array}$ & & $\begin{array}{l}\text { Settlements were } \\
\text { moved } 4 \mathrm{~km} \text { far } \\
\text { from the old }\end{array}$ & $\begin{array}{l}\text { It was emphasized that user demands } \\
\text { and the physical structure of the } \\
\text { regions were not considered in }\end{array}$ \\
\hline
\end{tabular}




\begin{tabular}{|l|l|l|l|}
\hline & $\begin{array}{l}\text { settlement (Enginöz } \\
\text { \& Ünlü, 2010). }\end{array}$ & $\begin{array}{l}\text { permanent housing applications } \\
\text { implemented in Dinar (Enginöz, } \\
\text { 2004: 20). }\end{array}$ \\
\hline $\begin{array}{l}\text { 1999- } \\
\text { Marmara }\end{array}$ & $\begin{array}{l}\text { New residential } \\
\text { areas were } \\
\text { established. }\end{array}$ & $\begin{array}{l}\text { In some settlements built after the } \\
\text { 1999 earthquake, houses were left } \\
\text { empty for many years without being } \\
\text { used (İnal \& Ünlü, 2009:104). }\end{array}$ \\
\hline 2003- Bingol & $\begin{array}{l}\text { Residential area in } \\
\text { the city center was } \\
\text { selected for rural } \\
\text { housing (Kürüm } \\
\text { Varolgüneş, 2019: } \\
\text { 207). }\end{array}$ & $\begin{array}{l}\text { Settlements created after the 2003 } \\
\text { Bingöl earthquake were either } \\
\text { changed or completely abandoned } \\
\text { (Kürüm Varolgüneş, 2020). }\end{array}$ \\
\hline 2011- Van & & $\begin{array}{l}\text { Mistakes made in the selection of the } \\
\text { housing sites after the 2011 Van } \\
\text { Earthquake caused dissatisfaction of } \\
\text { the disaster victims (K1lc1 et al, 2015: } \\
\text { 329). }\end{array}$ \\
\hline
\end{tabular}

\section{Meeting the user requirement}

It is very important to produce housings with different qualifications in terms of meeting the needs of each user. For this reason, social researches and various surveys should be conducted during the postdisaster sheltering stages, and housing features should be determined and produced with user participation. Instead of implementing certain types of pre-determined projects in every disaster area, solutions specific to the region should be produced and the adaptation of the housings and therefore of the occupants to local conditions should be ensured. Permanent residences, either wooden or concrete, were built in the settlement established after the 1975 Lice earthquake. The parcels were designed as $450 \mathrm{~m}^{2}$ in order to build a barn and a hayloft beside the houses of the disaster victims (UNDRO, 1982). A flat area was determined for the new settlement, but this area could not provide the climatic advantages of the old district center established on the mountain slope. Due to the preference of flat land, some of the agricultural areas were zoned for housing and were taken out of agricultural use. Since permanent residences could not meet the vital, cultural and regional needs of the people, they could not be embraced by the disaster victims (Coburn \& Spence, 2002). Since the types of houses built after the Erzurum-Kars earthquake approached the traditional typology, they differed from the permanent residences built before. In this respect, it can be said that building a house in the typology with which the disaster victims are familiar provides different experiences. It has been stated that the housings built in previous disasters were not used due to reasons such as not choosing the settlement regions correctly, the plan layout's not coinciding with the culture of the local community, or the houses' not having sufficient space (Aysan, 1985: 23). General problems identified in permanent housing production after the disaster before 1980 can be summarized as follows: the houses could not be produced in quantities to meet the needs and in equal distribution; the housings were remained empty since they were not liked by their occupants; and the production was not completed on time (Sey \& Tapan, 1987:52).

\section{Housing design}

Until the 1970s, using uniform designs was preferred in order to make the reconstruction process more economical, to build a large number of houses in large areas. However, while constructing these houses, attention was not paid to the differences in the conditions and needs of the disaster victims. Issues such as the settlement arrangement of the housings on the land, parcel sizes, and distances between the housings were mostly ignored. Not foreseeing that the housings could be developed and expanded with various additions in the future was an important problem. Studies conducted in disaster areas emphasized that additional structures such as animal shelters, storage areas for field products, breadbaking areas were randomly located near the houses. The fact that disaster housings were incompatible 
with people's lifestyles is another very general problem. Aysan and Oliver emphasized that four-room and single-story prefabricated houses built after the 1970 Gediz earthquake were incompatible with the lifestyles of disaster victims who had large family structures and engaged in agriculture and animal husbandry (Aysan \& Oliver, 1987). After the 1992 Erzincan earthquake, the application of building type with 12 flats was started. The fact that contractors and consultancy firms had gone through a preparation period in their work and during the design phase, and that experienced teams were involved in all stages of production, showed that the restructuring program adopted a different approach than the programs that had been implemented after other earthquakes. Two types of permanent housing were built after the 1995 Dinar earthquake. Some of these housings were tunnel system apartment type which had four floors and sixteen flats, and apartment type which had twelve flats with shops on the ground floor. The other is the detached single-story masonry housing type. These houses were evaluated positively by the users when they were first built because they were more modern and robust than the residences in the old residential area (Karanci \& Aksit, 1999: 35). However, after about eight years, they were evaluated negatively in terms of functionality by the disaster victims who were used to rural life. Housings that did not have a flexible structure were abandoned over time when they could not be developed according to needs (Enginöz, 2004). Permanent housings built in Gölyaka after the 1999 Marmara earthquake were not found functional as they were very small and with a single bathroom. Moreover, since the houses were not designed flexibly, they did not offer the opportunity to make changes and this resulted in the disaster victims' dissatisfaction. Housings that were not suitable for large and crowded family structures were abandoned in time (İnal \& Ünlü, 2009: 103). According to the studies, it is revealed that the settlements and housings designed after the earthquakes neither were embraced by the communities nor were adapted to lifestyles by changing and they were or abandoned if they had not been provided with this flexibility. Researchers revealed that the physical, economic, social, cultural, and psychological features of the existing settlement were not considered in a holistic manner while designing permanent housings settlements and structures after the earthquake. They foresee that design understanding in a structure should involve all these factors.

\section{Materials used for housing}

After the disaster, ignoring the industrial conditions of the region and not using local construction techniques and materials that were tried previously, especially in permanent housing projects in small and economically weak regions, resulted in significant problems (Coburn \& Spence, 2002). Using local resource ensures fast and economical procurement of materials and labours after disasters, and supports the creation of solutions suitable for life styles. When the studies were examined, it is observed that the materials used in permanent housings built after 1970 were not suitable for local conditions. Dikmen stated that the preference of concrete for the building of permanent housings after the $1970 \mathrm{Gediz}$ earthquake resulted in a situation where buildings was considered as damp and cold by users who had the habit of sitting on the ground and that the floors were covered with wooden material by the disaster victims (Dikmen \& Elias-Ozkan, 2004: 167). Enginöz stated that disaster victims complained that the masonry houses, which were built after the 1995 Dinar earthquake with hollow bricks and which did not have heat and water insulation, were cold in winter and hot in summer, unlike the old mud-brick houses (Enginöz, 2004: 22).

\section{Empowerment of the community}

The most important view that has been advocated in post-disaster practices since the 1980s is that housing is process needs to be supported, rather than being given as ready-made to disaster victims (Aysan \& Oliver, 1987; Coburn \& Spence, 2002). The housing policies implemented by the World Bank after the 1980s also developed in this direction. According to this policy, increasing the regional knowledge and skill in building technique, design, and material quality, and in this way ensuring that people form their own housing solutions have gained more importance (İnal \& Ünlü, 2009:103). Zetter and Boano (2010) also interpret post-disaster restructuring as meeting material needs and solving social needs through experts with active user participation and evaluate these as a process. Examples examined in Turkey show that the central authority is at the forefront in the process of housing production after 
earthquakes (Table 4). Inclusion of earthquake victims in the processes has been tried especially in rural areas but remained at the micro-level. When the permanent housing project processes and results implemented after the disasters in Turkey are examined, it is observed that the stages in which disaster victims are included or co-operation is provided are more successful than the stages in which they are not included. The issues from which disaster victims are dissatisfied or complained about are observed to stem from the points where participation and transparency cannot be achieved. Engagement of the society accompanies a variety of approaches at macro-level: The removal of the single-center management system, local democratization, dissemination of decision-making process among local organizations, community involvement in the development of resettlement and reconstruction policies, civil society debate, etc. (Davidson et al, 2007: 110).

Table 4. The activities and actors in the resettlement work conducted after earthquakes in Turkey

\begin{tabular}{|c|c|c|c|c|c|c|}
\hline & $\begin{array}{c}\text { Program } \\
\text { initiation } \\
\text { (leading } \\
\text { role in } \\
\text { procuring } \\
\text { the master } \\
\text { program of } \\
\text { reconstruct } \\
\text { ion) }\end{array}$ & $\begin{array}{c}\text { Project } \\
\text { initiation } \\
\text { (leading role } \\
\text { in starting the } \\
\text { project) }\end{array}$ & $\begin{array}{l}\text { Project } \\
\text { financing }\end{array}$ & Design & $\begin{array}{c}\text { Constructi } \\
\text { on }\end{array}$ & $\begin{array}{c}\text { Post- } \\
\text { project } \\
\text { modificatio } \\
\text { ns- } \\
\text { additions }\end{array}$ \\
\hline $\begin{array}{l}\text { l970-Gediz } \\
\text { (Kütahya) }\end{array}$ & Government & Government & Government & Government & \begin{tabular}{|c|} 
Hired \\
contractors
\end{tabular} & Beneficiaries \\
\hline 1971-Bingöl & Government & Government & Government & Government & Government & Beneficiaries \\
\hline 1975-Lice & $\begin{array}{c}\text { Government } \\
\text { NGOs }\end{array}$ & Government & Government & Government & Government & Beneficiaries \\
\hline $\begin{array}{l}\text { 1983-Erzurum- } \\
\text { Kars } \\
\end{array}$ & $\begin{array}{c}\text { Government } \\
\text { NGOs }\end{array}$ & Government & Government & Government & Government & Beneficiaries \\
\hline 1992-Erzincan & $\begin{array}{c}\text { Government } \\
\text { NGOs }\end{array}$ & $\begin{array}{c}\text { Government } \\
\text { NGOs } \\
\text { Beneficiaries }\end{array}$ & $\begin{array}{c}\text { Government } \\
\text { NGOs } \\
\text { Private } \\
\text { donors }\end{array}$ & $\begin{array}{c}\text { Government } \\
\text { Private firm }\end{array}$ & $\begin{array}{c}\text { Hired } \\
\text { contractors } \\
\text { Private firm }\end{array}$ & Beneficiaries \\
\hline $\begin{array}{l}\text { 1995-Dinar } \\
\text { (Afyon) }\end{array}$ & $\begin{array}{c}\text { Government } \\
\text { NGOs }\end{array}$ & & & & & Beneficiaries \\
\hline $\begin{array}{l}\text { 1999-Doğu } \\
\text { Marmara }\end{array}$ & Government & \begin{tabular}{|c|} 
Government \\
NGOs \\
Beneficiaries
\end{tabular} & $\begin{array}{c}\text { Government } \\
\text { NGOs } \\
\text { Private } \\
\text { donors }\end{array}$ & $\begin{array}{l}\text { Government } \\
\text { Private firm }\end{array}$ & $\begin{array}{c}\text { Hired } \\
\text { contractors } \\
\text { Private firm }\end{array}$ & Beneficiaries \\
\hline 2003-Bingöl & Government & Government & Government & Government & \begin{tabular}{|c|} 
Hired \\
contractors \\
Private firm \\
\end{tabular} & Beneficiaries \\
\hline 2011-Van & $\begin{array}{c}\text { Government } \\
\text { NGOs }\end{array}$ & $\begin{array}{c}\text { Government } \\
\text { NGOs } \\
\text { Beneficiaries }\end{array}$ & $\begin{array}{c}\text { Government } \\
\text { NGOs } \\
\text { Private } \\
\text { donors } \\
\end{array}$ & $\begin{array}{l}\text { Government } \\
\text { Private firm }\end{array}$ & $\begin{array}{c}\text { Hired } \\
\text { contractors } \\
\text { Private firm }\end{array}$ & Beneficiaries \\
\hline
\end{tabular}

\section{Easy and fast production}

In the 1992 Erzincan earthquake, tunnel system technology was preferred to ensure the rapid and large number of housing production. Since this construction technology does not require a large capital investment and integration of the existing workforce and equipment is easy in this technology, it has been also used frequently after the 1999 Marmara earthquake. Before making decisions related to 
disaster housing design, it is necessary to have a design model which includes information related to the socio-demographic and cultural characteristics, disaster experiences, and space usage habits in disaster areas, the user participation, the post-use evaluations, and the design guides that are created for future use (Enginöz \& Ünlü, 2010).

\section{Building quality}

Another issue that is considered while creating new residential areas is to concentrate on damage reduction efforts that will ensure the resilience of the settlement and society against possible disasters that will occur from now on. For this reason, it is significant that new housings and other buildings, which will be constructed, should meet the disaster resistance criteria. Failure to give sufficient importance to issues such as climate, infrastructure, and topography causes users to encounter problems. An essential factor to talk about user satisfaction in permanent housing production is ensuring the comfort of the building. Nevertheless, only if these comfort conditions are met in an energy-efficient manner, the building quality can be mentioned. Accordingly, housing designs that are suitable for the climate, that use renewable energy sources as much as possible and consume less energy should be developed. The use, conservation and transformation of existing resources should be ensured. Correct positioning, correct orientation, natural ventilation lighting, and heat recovery in residential areas will constitute necessary design inputs.

\section{Provision of social infrastructure}

Disaster housing should generally be produced in accordance with climatic, social and economic conditions. It was determined that in housings users' needs such as privacy and security were often not met. Kennedy points out that post-disaster reconstruction needs to be "better built" in terms of safety, security and livelihoods (Kennedy et al, 2008: 30). The occupants of disaster housings built in Turkey firstly added elements such as courtyard walls and window bars in order to ensure their privacy and security. Prefabricated houses produced in the Eastern Anatolia Region were not accepted on the grounds that they are not resistant to attacks from outside. The examinations and researches conducted to examine social sustainability in permanent housing settlements built after the earthquake revealed that in order to ensure social sustainability, besides meeting the basic needs like sheltering, it is also necessary to provide common places, which aimed at provision of health, high quality, security, social diversity, and belonging. It has been concluded that it is necessary to ensure the following criteria and parameters: searching for local-specific solutions that will create and perpetuate communities, creating common use places and sheltering places that will support local architecture and belonging, addressing and protecting demographic and social structure and neighbourhood relations, establishing communityspecific infrastructure and social spaces, adopting flexible planning understanding and ensuring participation, providing infrastructure and cultural areas and service areas that will appeal to today and ensuring their accessibility.

\section{CONCLUSIONS}

The urgency of post-disaster housing production brings many problems. However, it is of great importance to evaluate the work done in order to learn from experiences and to prevent the repetition of the problems. The process of designing new residential areas affects the settlement pattern significantly. The characteristics of the housing units determine the quality of that settlement, its adoption by the users, and its state of use. In this sense, it is critical to examine the post-disaster housing production process in terms of the product and its use, in terms of providing data for similar settlements to be produced nowadays. In this sense, it is important to examine the post-disaster housing production process in terms of product and use, in terms of providing data for similar settlements to be produced today.

In addition, the studies demonstrated that the following criteria were not taken into when deciding the sites of settlements: the distance to neighbouring villages and the city centre, the structure of the ground, distance to water resources, existence of cadastral work and maps, easy access to construction materials. In the works examined, housing constructions are generally carried out by the state. However, it is 
observed that the building of the houses by the victims is also applied as an alternative method especially in rural areas. Especially after the 1980s, the most important view in post-disaster applications is that housing construction should be a process that should be supported rather than being provided as readymade. The housing policies implemented by the World Bank after the 1980s also developed in this direction. According to this policy, increasing the regional knowledge and skill in building technique, design, and material quality, and in this way ensuring that people form their own housing solutions have gained more importance (Kürüm Varolgüneş, 2020). It is observed that settlements formed with applications where people are organized to produce their own solutions had more success (Coburn \& Spence, 2002).

The ensuring that the life in settlements established following a disaster is sustainable in terms of all dimensions such as physically, socially, culturally, and economically will also enable the long-term use of permanent housings. It was observed that most of the disaster housings built in the 50 years between 1970 and 2020 do not carry the traces of the local patterns. Issues related to addressing local factors and meeting local needs have continued to be criticized in spite of all the years that have passed. When the results of analysis are evaluated, the importance of an approach that integrates environmental functions and socio-economic structure while creating new residential areas has been revealed. This holistic approach will ensure that community-based indicators are also included in the production of durable permanent housing.

When the general evaluation of the study results is made:

- Before moving on to physical planning after the earthquake, data collection and evaluation studies should be conducted on the user, housing and environment. This is only possible with preliminary studies before the earthquake. Before earthquakes occur, residential types that consider user needs should be developed. These houses should be designed considering the climate, geological structure, social and cultural characteristics of the region where they are located.

-The reconstruction process after earthquakes in Turkey is seen as a technical process, and consequently, the physical dimension is emphasized while creating new residential areas. Nonetheless, researches reveal that practices that consider social, cultural and psychological needs in new settlements after disasters are more effective on user satisfaction. The creation of social infrastructure and facilities in which disaster victims can connect with their previous settlements, especially in disaster residences created in new settlements, will enable them to develop a sense of belonging more quickly and social recovery to be faster.

- In post-disaster permanent housing projects, user participation should be included in all processes starting from design decisions in order to ensure satisfaction. The workforce of the local people should be utilized in housing production, and the materials available in the region should be given priority. The experiences gained during the process should be considered as design input for later disasters.

To summarize, decisions to be taken with user participation in all stages of the design and construction of permanent housings needed after disasters and the experiences to be obtained during the process should be evaluated as design inputs for later disasters. In this context, the preparation of design guides in which the inputs obtained during the pre-disaster design, construction and use stages are collected will enable post-disaster housing designs that are suitable for the nature of the victims living in rural settlements or cities and that meet their expectations and preferences.

\section{REFERENCES}

AFAD. (2018) All Earthquakes in Turkey, Disaster and Emergency Management Authority, https://www.afad.gov.trl, Accessed date: 17 September 2018.

Arslan H. (2007) Re-design, re-use and recycle of temporary houses. Building and Environment 42: 400-406.

Aysan FY. (1985) The Erzurum-Kars earthquake area revisited. Disasters 9: 23-31. 
Aysan Y and Oliver P. (1987) Housing and Culture after Earthquakes: A guide for future policy making on housing in seismic areas, Oxford: Oxford polytechnic.

Baradan B. (2008) Review of Literature for the concept of post-disaster housing in Turkey. Gazi University Journal of Science 21: 43-49.

Bilau AA, Witt E and Lill I. (2017) Analysis of measures for managing issues in post-disaster housing reconstruction. Buildings 7: 29.

Boelhouwer P and van der Heijden H. (2018) The effect of earthquakes on the housing market and the quality of life in the province of Groningen, the Netherlands. Journal of Housing and the Built Environment: 1-10.

Coburn A, Leslie J and Tabban A. (1984) Reconstruction and resettlement 11 years later: a case study of Bingöl Province, Eastern Turkey. Earthquake relief in less industrialized areas. International symposium. 49-56.

Coburn A and Spence R. (2002) Earthquake protection, Chichester: John Wiley \& Sons.

Davidson CH, Johnson C, Lizarralde G, et al. (2007) Truths and myths about community participation in post-disaster housing projects. Habitat international 31: 100-115.

Davoudi S and Madanipour A. (2015) Reconsidering localism, New York: Routledge.

Dias NT, Keraminiyage K and DeSilva KK. (2016) Long-term satisfaction of post disaster resettled communities: The case of post tsunami-Sri Lanka. Disaster Prevention and Management: An International Journal 25: 581-594.

Dikmen N and Elias-Ozkan ST. (2004) Post-Disaster Housing in Rural Areas of Turkey. Second International Conference on Post-Disaster Reconstruction in Developing Countries. Citeseer.

Dikmen N and Elias-Ozkan ST. (2016) Housing after disaster: a post occupancy evaluation of a reconstruction project. International Journal of Disaster Risk Reduction 19: 167-178.

Einali J, Yeganeh BM, Cheraghi M, et al. (2020) Evaluating the effects of reconstruction of the damaged villages in the 2002 earthquake in Avaj, Iran. International Journal of Disaster Risk Reduction 43: 101373.

Enginöz E. (2004) A study in post-disaster home environments: a comparative case study between people living in villages and in the town center of Dinar, Turkey. Second International Conference on Post-Disaster Reconstruction in Developing Countries.

Enginöz EB and Ünlü A. (2010) The evaluation of design in post-disaster houses: the case of AfyonDinar İTÜDERGISII/a 5 .

Fallahi A. (2007) Lessons learned from the housing reconstruction following the Bam earthquake in Iran. Australian Journal of Emergency Management 22: 26.

Félix D, Monteiro D, Branco JM, et al. (2015) The role of temporary accommodation buildings for post-disaster housing reconstruction. Journal of Housing and the Built Environment 30: 683-699.

Freeman PK. (2004) Allocation of post-disaster reconstruction financing to housing. Building Research \& Information 32: 427-437.

Gomaa B and Sakr N. (2015) Social Sustainability; Maintenance of Socio-Cultural Characteristics: A Case Study of El-Raml Station. European Journal of Sustainable Development 4: 203-203.

Guri-Rozenblit S. (1989) Effects of a tree diagram on students' comprehension of main ideas in an expository text with multiple themes. Reading Research Quarterly: 236-247. 
Hamilton N. (2012) Post-disaster shelter: A studio-based response to emergency shelter in natural disaster zones. Sustainable futures: Architecture and urbanism in the global south, Kampala, Uganda 2730.

Hayles CS. (2010) An examination of decision making in post disaster housing reconstruction. International Journal of Disaster Resilience in the Built Environment 1: 103-122.

İnal E and Ünlü A. (2009) Türkiye'de afet sonrası kalıcı konutlarda esneklik kavramının değerlendirilmesi. ITÜDERGISİ/a 8.

Ishiwatari M. (2014) Institution and governance related learning from the East Japan Earthquake and Tsunami. In: (eds) SR (ed) Disaster Recovery. Disaster Risk Reduction (Methods, Approaches and Practices). Tokyo: Springer, 77-88.

Johnson C. (2007) Impacts of prefabricated temporary housing after disasters: 1999 earthquakes in Turkey. Habitat international 31: 36-52.

Karanci NA and Aksit B. (1999) Strengthening community participation in disaster management by strengthening governmental and non-governmental organisations and networks: A case study from Dinar and Bursa (Turkey). Australian Journal of Emergency Management, The 13: 35.

Karunasena G and Rameezdeen R. (2010) Post-disaster housing reconstruction: Comparative study of donor vs owner-driven approaches. International Journal of Disaster Resilience in the Built Environment 1: 173-191.

Kennedy J, Ashmore J, Babister E, et al. (2008) The meaning of 'build back better': evidence from post-tsunami Aceh and Sri Lanka. Journal of contingencies and crisis management 16: 24-36.

Kılc1 F, Kara BY and Bozkaya B. (2015) Locating temporary shelter areas after an earthquake: A case for Turkey. European journal of operational research 243: 323-332.

Kürüm Varolgüneş F. (2019) Evaluation of vernacular and new housing indoor comfort conditions in cold climate - a field survey in eastern Turkey. International Journal of Housing Markets and Analysis 13: 207-226.

Kürüm Varolgüneş F. (2020) Post-disaster permanent housing: the case of the 2003 Bingöl earthquake in Turkey.

Lagorio HJ. (1990) Earthquakes: an architect's guide to nonstructural seismic hazar ds.

Limoncu S and Bayülgen C. (2005) Türkiye'de afet sonrası yaşanan barınma sorunları. Megaron 1: 18.

Manatunge JMA and Abeysinghe U. (2017) Factors affecting the satisfaction of post-disaster resettlers in the long term: A case study on the resettlement sites of tsunami-affected communities in Sri Lanka. Journal of Asian Development 3: 94-124.

Oliver-Smith A. (1991) Successes and failures in post-disaster resettlement. Disasters 15: 12-23.

Ophiyandri T, Amaratunga D and Keraminiyage K. (2016) Advantages and limitations of communitybased post-disaster housing reconstruction projects. International Journal of Disaster Resilience in the Built Environment 7: 420-431.

Özkan S. (1972) Deprem Konutlarında Değişik Bir Seçenek: Köpük Kubbeler. Mimarlık Dergisi 3: 25-28.

Peacock WG, Dash N, Zhang Y, et al. (2018) Post-disaster sheltering, temporary housing and permanent housing recovery. Handbook of Disaster Research. Springer, 569-594.

Perera T, Weerasoori I and Karunarathne H. (2012) An evaluation of success and failures in Hambantota, Siribopura resettlement housing program: lessons learned. Sri Lanka Journal of Real Estate. 
Platt S and Drinkwater BD. (2016) Post-earthquake decision making in Turkey: Studies of Van and Izmir. International Journal of Disaster Risk Reduction 17: 220-237.

Quarantelli EL. (1995) Patterns of sheltering and housing in US disasters. Disaster Prevention and Management 4: 43-53.

Sey Y and Tapan M. (1987) Afet Sonrasında Barınma ve Geçici Konut Sorunu Raporu. Yayınlanmamış Akademik Çalışma, İTÜ, İstanbul.

Steinberg F. (2007) Housing reconstruction and rehabilitation in Aceh and Nias, Indonesia-Rebuilding lives. Habitat international 31: 150-166.

Takesada N, Manatunge J and Herath IL. (2008) Resettler choices and long-term consequences of involuntary resettlement caused by construction of Kotmale Dam in Sri Lanka. Lakes \& Reservoirs: Research \& Management 13: 245-254.

Tas N, Cosgun N and Tas M. (2007) A qualitative evaluation of the after earthquake permanent housings in Turkey in terms of user satisfaction-Kocaeli, Gundogdu Permanent Housing model. Building and Environment 42: 3418-3431.

UNDRO. (1982) Shelter After Disaster: Guidelines for Assistance, New York: Office of the United Nations Disaster Relief Co-Ordinator,United Nations.

Zetter R and Boano C. (2010) Space and place after natural disasters and forced displacement, Oxford and New York: Spon Press. 